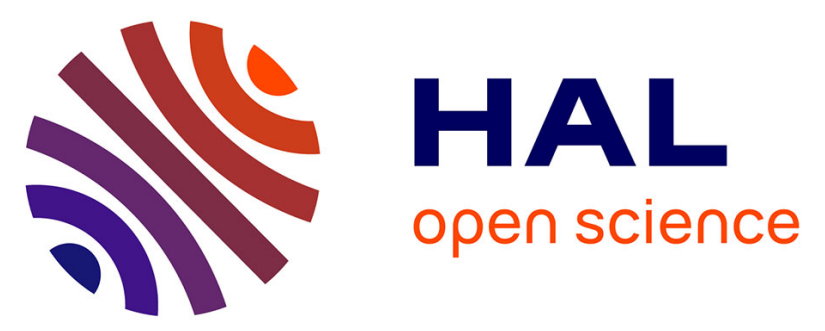

\title{
Microscale evidence for a high decrease of soil bacterial density and diversity by cropping
}

Florentin Constancias, Nicolas Chemidlin Prévost-Bouré, Sébastien Terrat, Simon Aussems, Virginie Nowak, Jean-Philippe Guillemin, Aline Bonnotte, Luc Biju-Duval, Aline Navel, Jean Martins, et al.

\section{To cite this version:}

Florentin Constancias, Nicolas Chemidlin Prévost-Bouré, Sébastien Terrat, Simon Aussems, Virginie Nowak, et al.. Microscale evidence for a high decrease of soil bacterial density and diversity by cropping. Agronomy for Sustainable Development, 2014, 34 (4), pp.831-840. 10.1007/s13593-0130204-3 . hal-01234825

\section{HAL Id: hal-01234825 \\ https://hal.science/hal-01234825}

Submitted on 27 Nov 2015

HAL is a multi-disciplinary open access archive for the deposit and dissemination of scientific research documents, whether they are published or not. The documents may come from teaching and research institutions in France or abroad, or from public or private research centers.
L'archive ouverte pluridisciplinaire HAL, est destinée au dépôt et à la diffusion de documents scientifiques de niveau recherche, publiés ou non, émanant des établissements d'enseignement et de recherche français ou étrangers, des laboratoires publics ou privés. 


\title{
Microscale evidence for a high decrease of soil bacterial density and diversity by cropping
}

\author{
Florentin Constancias • Nicolas Chemidlin Prévost-Bouré • Sébastien Terrat • \\ Simon Aussems • Virginie Nowak • Jean-Philippe Guillemin • Aline Bonnotte • \\ Luc Biju-Duval • Aline Navel • Jean MF Martins • Pierre-Alain Maron • Lionel Ranjard
}

Accepted: 27 November 2013 / Published online: 24 December 2013

(C) INRA and Springer-Verlag France 2013

\begin{abstract}
Soil microbes play major agricultural functions such as the transformation of soil organic matter into plant fertilizers. The effects of agricultural practices on soil microbes at the scale of plots, from meters to hectare, are well documented. However, the impact at soil microscale, from micrometers to millimeters, is much less known. Therefore, we studied bacterial community density and diversity at microscale in crop soil under grassland, tillage, and no tillage. We fractionated macroaggregates, from 2,000 to $250 \mu \mathrm{m}$ and from 250 to $63 \mu \mathrm{m}$; microaggregates, from

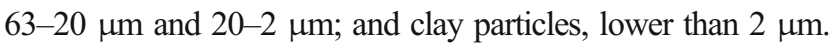
We measured the bacterial density and diversity by real-time PCR and 454-pyrosequencing of 16S rRNA genes of soil DNA, respectively. Results show that bacterial density and diversity were heterogeneous among size aggregates. Tillage decreased bacterial density from 22 to $74 \%$, and diversity from 4 to $11 \%$, and changed taxonomic groups in micro- and macroaggregates. This change led to the homogenization of bacterial communities
\end{abstract}

F. Constancias $\cdot$ S. Aussems $\cdot$ V. Nowak $\cdot$ L. Biju-Duval .

P.-A. Maron $\cdot$ L. Ranjard $(\bowtie)$

INRA, UMR 1347 Agroécologie, BP 86510, 21000 Dijon, France

e-mail: ranjard@dijon.inra.fr

N. C. Prévost-Bouré • J.-P. Guillemin

AgroSup Dijon, UMR1347 Agroecologie, BP 86510, 21000 Dijon, France

\section{A. Bonnotte}

Université de Bourgogne, UMR1347 Agroécologie, Plateforme

DlmaCell, BP 86510, 21000 Dijon, France

S. Terrat $\cdot$ V. Nowak $\cdot$ P.-A. Maron $\cdot$ L. Ranjard

INRA, UMR1347 Agroecologie, Plateforme GenoSol, BP 86510, 21000 Dijon, France

A. Navel · J. M. Martins

CNRS, UMR 5564, Laboratoire des transferts en hydrologie et en

Environnement, Université Joseph Fourier, Grenoble, France and is explained by a higher protection of microaggregates. As a consequence, microaggregates contained similar bacterial communities whatever the land management is, whereas strong differences were observed between communities inhabiting macroaggregates. These findings demonstrate that bacterial diversity in microaggregates was mainly controlled by historical contingency, whereas bacterial communities in macroaggregates are shaped by contemporary perturbations. Our findings thus revealed unprecedented insights of the effect of agriculture on soil microbes. Potential applications include using crop management options that preserve macroaggregate structure to promote soil heterogeneity and therefore microbial diversity.

Keywords Bacterial diversity $\cdot$ Soil microscale $\cdot$ Soil disturbance $\cdot$ Agricultural practices $\cdot$ Microbial habitat

\section{Introduction}

Soil is the principal reservoir of biodiversity with arguably the highest prokaryotic diversity on our planet. One gram of soil was found to host up to 10 billion microorganisms and thousands of different species (Martiny et al. 2006). Although the importance of soil microbes in driving numerous biological and ecological processes is now well known, our understanding on the distribution and role of soil microbial community and its response to environmental perturbations remains limited (Prosser et al. 2007). This knowledge gap is partly due to technical limitations, i.e., difficulties in characterizing microbial diversity due to the poor accessibility of indigenous microbial populations within the heterogeneous and structured soil matrix, as well as in deciphering information that represents 100,000 to 1,000,000 different species per gram of soil (Maron et al. 2011). However, recent methodological developments led to powerful molecular tools, which now 
allow fine characterization of indigenous soil microbial communities (Delmont et al. 2011).

During the last decade, microbial ecologists have deeply investigated the diversity of soil microbes on a wide scale to better understand the diversification processes of microbes and rank the influence of environmental filters (Martiny et al. 2006). These studies revealed that microbial abundance (Dequiedt et al. 2011) and diversity (Fierer and Jackson 2006) were spatially structured on a wide scale and were mainly driven by local soil characteristics $(\mathrm{pH}, \mathrm{C} / \mathrm{N}$ ratio, and soil texture), plant cover, and land management rather than by distal parameters (geomorphology, climate). At a finer scale (i.e., landscape or plots), the heterogeneous and nonrandom distribution of the abundance and diversity of soil microbial communities has been also demonstrated with a significant influence of soil characteristics $(\mathrm{pH}$, water content, carbon, and nitrogen), plant cover, and land management (Zinger et al. 2011; Lienhard et al. 2013).

Although these recent studies allowed increasing our knowledge on the environmental drivers shaping soil microbial diversity on large spatial scales, little is known about the variability of bacterial diversity at the microscale. At this scale, soil provides a mosaic of microenvironments differing in their nutrient, water, and oxygen availability, as well as in $\mathrm{pH}$ and size of pores available for microbial colonization (Ranjard and Richaume 2001), hence providing as much environmental variability as the wider scale (Mummey et al. 2006). Direct soil observations (Nunan et al. 2003) as well as measurements of microbial abundance and of bacterial community composition and diversity (Ranjard et al. 2000; Mummey et al. 2006; Davinic et al. 2012) evidenced the heterogeneous distribution of indigenous communities. At this scale, the main environmental driver is soil porosity influencing soil aeration, water availability, as well as nutrient resources (Mummey et al. 2006; Vos et al. 2013). However, we still lack knowledge on the ecology of microbial communities in soil microenvironments, in terms of diversity distribution, regulation, and evolution in response to environmental perturbations and especially to agricultural land management.

Among agricultural practices, tillage is generally described as having the greatest impact on biological properties with a strong physical disturbance of soil, leading to a decrease of soil macroaggregate content (Oorts et al. 2007), to changes in soil water content, temperature, aeration, and of soil organic status (Six et al. 2004). Consequently, it appears now crucial to better evaluate the impact of tillage and cropping intensity on microbial community at a microscale that corresponds to the scale of microbial biotic and trophic interactions. This strategy should provide a better understanding and prediction of the overall image of community assembly in bulk soils and a better understanding on soil biological functioning and the ecosystem services provided by soil microorganisms (Hol et al. 2010).

In this study, our aim was to describe the impact of cropping intensity and soil disturbance on bacterial abundance and diversity at the scale of soil microenvironments. We optimized a soil fractionation procedure to separate microand macroaggregates from a soil under different cropping intensity (i.e., grassland vs no-till cropland vs tilled cropland). Five size classes of aggregates and particles were isolated by soil fractionation $(2,000-250,250-63,63-20,20-2$, and $<2 \mu \mathrm{m}$ ) for each soil. Environmental variables (organic carbon and total nitrogen contents) were measured in each microenvironment. Bacterial density and diversity were characterized by using real-time PCR and 454-pyrosequencing on $16 \mathrm{~S}$ rRNA gene, respectively, on metagenomic DNA directly extracted from soil microenvironments. The analysis of the changes in particular taxonomic groups' distribution among microenvironments was used to evaluate agricultural practice effect on soil ecological status and biological functioning.

\section{Materials and methods}

\subsection{Site description and soil sampling}

Soils were sampled in spring 2011 from three plots of the same soil type (silty clay calcisol) located in the agricultural landscape of Fénay (Lat $47^{\circ} 14^{\prime} 37^{\prime \prime} \mathrm{N}$, Long $5^{\circ} 03^{\prime} 36^{\prime \prime} \mathrm{E}$, Burgundy, France) where the agricultural practices have been recorded for 8 years before the sampling period. A grassland plot (G, unpastured meadow plot frequently mowed since 2002) and two cultivated plots under the same crop rotation (rape, wheat, barley) were selected. One was tilled every year (T), and the other one was not tilled but only stubble ploughed (NT) during the data collection period (Fig. 1). The different land use regime resulted in soil variants that differed in their level of SOC with only minor differences in other parameters. For each site, the sampling strategy consisted of a georeferenced central point with four others at $1 \mathrm{~m}$ in distance, in order to catch the local variability. Soil cores were collected from the surface horizon $(0-20 \mathrm{~cm})$ and were pooled. Soils were sieved $(2 \mathrm{~mm})$, and subsamples were air-dried for further bulk soil physicochemical analysis. The other portions of soils were stored at $4{ }^{\circ} \mathrm{C}$ until the fractionation procedure.

\subsection{Soil fractionation procedure}

A gentle physical soil fractionation method was adapted from Chotte et al. (2002) to isolate the soil microenvironments according to their size. A subsample of $50 \mathrm{~g}$ of fresh 2-mm sieved soil was shaken in $250 \mathrm{~mL}$ of Milli-Q water for $3 \mathrm{~h}$. After dispersion, the particles and water-stable aggregates were separated by wet sieving through two sieves of 250 - 

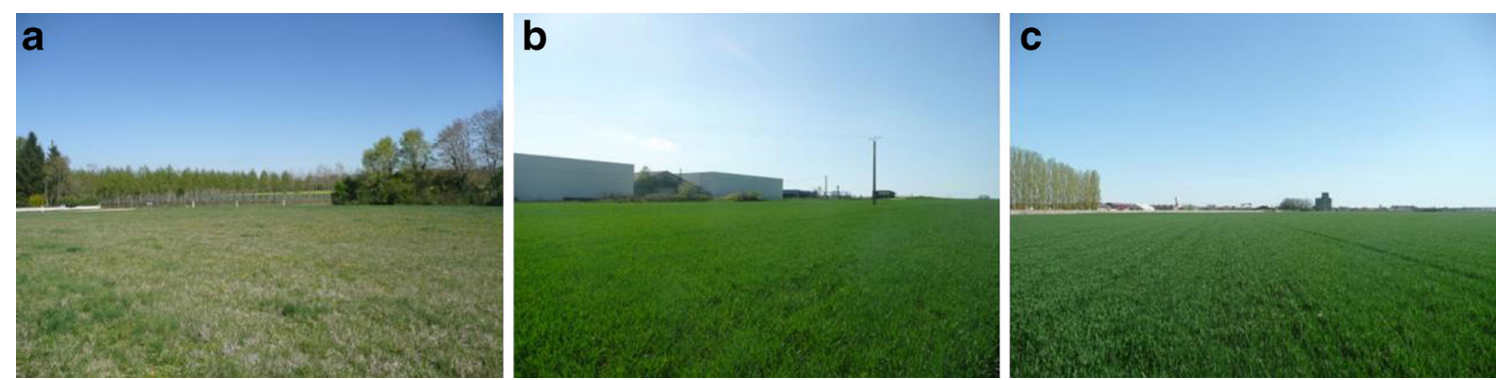

Fig. 1 Plots investigated under different cropping intensity in the Fénay landscape. a Grassland. b No till. c Till cropland

and $63-\mu \mathrm{m}$ mesh. The sieves were slowly raised and lowered in water (approximately $3 \mathrm{~cm}$ ) 60 times during $2 \mathrm{~min}$ to separate the fractions. The resulting 2,000-250- and 250$63-\mu \mathrm{m}$ fractions were macroaggregates associated to coarse and fine sands, respectively. The 63-20- and 20-2- $\mu \mathrm{m}$ fractions (microaggregates with particles of silt and loam, respectively) were separated by sedimentation and siphoning according to Stoke's law. The clay fraction of $<2 \mu \mathrm{m}$ consisting of dispersible clays and organic colloids was recovered by centrifuging at $11,000 \mathrm{~g}, 4^{\circ} \mathrm{C}$ for $20 \mathrm{~min}$. Water was removed from each fraction by centrifuging $\left(11,000 \mathrm{~g}, 4{ }^{\circ} \mathrm{C}, 20 \mathrm{~min}\right)$ before freeze-drying. The fractionation procedure was carried out in replicates so that enough material for each fraction could be recovered from the three soils. Replicates were lyophilized and stored at $-40{ }^{\circ} \mathrm{C}$, and three subsamples were used for physicochemical and microbiological analysis.

\subsection{Soil physicochemical analysis}

The lyophilized fractions were weighed to determine the relative mass distribution of the different size fractions. Organic $\mathrm{C}$ and total $\mathrm{N}$ contents of bulk soils and fractions were characterized according to NF ISO 10694 and 13878, respectively, and the $\mathrm{C} / \mathrm{N}$ ratio was deduced. Soil texture of bulk soils was determined according to NF X 31-107. Size distribution of the particles and aggregates of each fraction was verified by laser granulometry (Mastersizer 2000, Malvern Ltd).

\subsection{Scanning electron microscopy}

Samples were spread on adhesive graphite tabs mounted on aluminum stubs. Each specimen was then coated with goldpalladium (12-15 nm thick) using a Polaron SC 7620 Mini Sputter Coater (Quorum Technologies Ltd, Ashford, UK). Samples were observed with a Philips XL-30ESEM LaB6 scanning electron microscope at $14 \mathrm{kV}$.

\subsection{Soil DNA extraction and bacterial density}

Soil microbial DNA was extracted and purified from soil samples using the GnsGII procedure as described by Plassart et al. (2012). Bacterial density was estimated by real-time quantitative PCR (qPCR) of 16S rRNA gene (Plassart et al. 2012). 16S rRNA sequences were amplified with primers $341 \mathrm{~F}$ and $515 \mathrm{R}$ on $1 \mathrm{ng}$ of template DNA and using the Veriti ${ }^{\circledR}$ Thermal Cycler (Applied Biosystems ${ }^{\circledR}$, Life Sciences, USA).

2.6 Bacterial diversity: pyrosequencing and bioinformatic analysis

Microbial diversity was estimated by 454-pyrosequencing of the 16S rRNA V3-V4 gene region as described by Terrat et al. (2012). First, nested PCR was conducted, first using the primers F479 and R888. Then, a second PCR was conducted with purified PCR products from the first PCR, using ten base-pair multiplex identifiers (MID) added to the primers at 5 ' position to specifically identify each sample. Pyrosequencing was then carried out on a GS Junior (Roche Applied Science, Indianapolis, IN).

The data were processed using the GnS-PIPE of the GenoSol platform (http://www2.dijon.inra.fr/plateforme genosol/) described by Terrat et al. (2012). Raw sequences were discarded if they contained ambiguous base calls, were less than $350 \mathrm{nt}$ in length, or if they contained any ambiguity (Ns). The dereplicated reads were then aligned with infernal alignments that use secondary structure of $16 \mathrm{~S}$ rRNA gene sequences and then clustered at $95 \%$ sequence similarity into operational taxonomic units (OTU). Another filtering step was then applied to eliminate potential sources of errors (e.g., PCR chimeras, sequencing errors, OTU overestimation; Terrat et al. 2012). In order to efficiently compare the datasets, quality sample reads were reduced by random selection to the lowest dataset, i.e., 2,060 randomly quality-selected sequences per sample. High-quality reads were used for taxonomy-based analysis using similarity approaches (USEARCH) against dedicated reference databases from the Silva (Quast et al. 2013), with sequences longer than 500 nucleotides. Moreover, for taxonomy-independent analyses, several diversity and richness indices were determined using the defined OTU. Finally, we compared the bacterial communities from all samples using UniFrac (Lozupone and Knight 2005). UniFrac community analyses were based on a phylogenetic tree 
computed with FastTree using the most abundant read to represent each OTU. A weighted UniFrac distance measure was then realized to compute a dendrogram by using the PycoGent package (Knight et al. 2007). The raw data sets are available on the EBI database system under project accession number PRJEB4553.

\subsection{Statistical data analysis}

Differences between physicochemical characteristics, bacterial density, diversity, and similarity communities were tested by analysis of variance (ANOVA, multiple paired comparisons together with the Bonferroni correction, $P<0.05$ ).

The heatmap figure was built up by using the heatmap. 2 function implemented in gplots $\mathrm{R}$ package on the relative abundance values of the most dominant bacterial genus across the samples. Each row was scaled so that the mean of each taxonomic group across sample types was calculated and colored by a corresponding $Z$ score.

\section{Results and discussion}

The study on indigenous bacterial communities at a microscale requires efficient separation of the different microenvironments according to size and maintenance of their integrity in terms of aggregate stability and associated microbial community (Ranjard and Richaume 2001; Vos et al. 2013). Here, we optimized a fractionation procedure (energy applied, time of dispersion, wet sieving) suitably adapted to the studied soil type. Aggregate integrity was validated by comparing the redistribution of clay and silt particles from the coarse to fine fractions obtained by fractionation procedure with those of the textural particle analysis (data not shown) as well as by a scanning electron microscopy analysis providing visual evidence of the presence of stable macroaggregates in the coarse fractions (Fig. 2). In addition, soil fractionation experiments resulted in a complete mass recovery of fractions ranging from 96 to $98.1 \%$ of the bulk soil.

\subsection{Effect of agricultural management on physicochemical} characteristics of soil microenvironments

The fractions recovered from all the three soils showed similar mass distribution and were dominated by the $20-2-\mu \mathrm{m}$ size fraction (Table 1). Comparison of the relative proportions between the three soils revealed a significant decrease of the macroaggregated fractions $(2,000-250$ and $250-63 \mu \mathrm{m})$ according to cropping intensity (grassland 11.7 and $7.2 \%$ of the total soil weight $\geq$ no till 9.0 and $5.9 \%>$ tilled crop soil 7.2 and $4.2 \%$ ). This could be explained by the mechanical disruption of macroaggregates by tillage as well as by the loss of organic binding agents due to the stimulation of organic matter mineralization. These factors are both known to reduce the stability of soil macrostructures under cropping and tillage (Olchin et al. 2008).

In addition, agricultural practices modified significantly the balance of organic carbon and nitrogen contents between the coarse and fine fractions. Organic carbon contents ranged from 3.93 to $27.06 \mathrm{~g} \mathrm{~kg}^{-1}$ and total nitrogen contents from 2.59 to $0.30 \mathrm{~g} \mathrm{~kg}^{-1}$ depending on the soil and size fractions and were negatively correlated with cropping intensity (grassland soil $\geq$ no-till soil $>$ tilled soil, Table 1 ). Whatever the studied soil, the $\mathrm{C} / \mathrm{N}$ ratio decreased with the size of the fraction but increased significantly with soil tillage. Altogether these results indicated that, at a microscale, cropping intensity induced significant modifications in the surrounding soil conditions for microorganisms in terms of microhabitat stability and trophic conditions (Six et al. 2004; Oorts et al. 2007).

\subsection{Response of soil bacterial density to cropping intensity} at a microscale

Bacterial density varied significantly between bulk soils according to agricultural management, decreasing as follows: grassland $\left(5.610^{10} 16 \mathrm{~S}\right.$ rRNA gene copies per gram of sample) $\geq$ no-till $\left(4.210^{10}\right)>$ tilled crop soil $\left(2.710^{10}\right)$ (Fig. 3) This was positively correlated with the organic carbon $(r=$ $0.836)$ and total nitrogen contents $(r=0.830)$, but negatively with the $\mathrm{C} / \mathrm{N}$ ratio $(r=-0.682)$. Similar patterns of bacterial density distribution were observed between the different microenvironments whatever the land management. The 2,000250 - and $<20-\mu \mathrm{m}$ size fractions housed the highest bacterial density $\left(7.210^{10}\right.$ and $5.410^{10} 16 \mathrm{~S}$ rRNA gene copies per gram of sample, respectively), whereas the lowest density (8.1 $10^{9} 16 \mathrm{~S}$ rRNA gene copies per gram of sample) was found in the 63-20- $\mu \mathrm{m}$ fraction (Fig. 3). Since this distribution fitted with the distribution of organic carbon and nitrogen contents already observed on micro- and wide scales (Ranjard and Richaume 2001; Dequiedt et al. 2011), habitat structure and trophic conditions can therefore be considered as universal drivers of soil microbial abundance.

The significant decrease of bacterial density observed in bulk soils and microenvironments in crop systems (from 22 to $74 \%$ according to microenvironments, Fig. 3) compared to grassland is consistent with the loss of organic carbon and nitrogen as well as of the macroaggregated fractions due to cropping intensity (Six et al. 2004). This loss of nutrients under tillage is mainly due to an active microbial mineralization leading to a weak carbon storage, a relative accumulation of humified soil organic matter and, therefore, to an increase of the $\mathrm{C} / \mathrm{N}$ ratio (Oorts et al. 2007). In addition, this decrease led to strong homogenization of the microscale distribution of bacterial abundance, with a loss of more than $80 \%$ of the bacterial density variability between microenvironments of 
Fig. 2 Scanning electron microscopy pictures of the size fractions in grassland soil: a $2,000-250 \mu \mathrm{m}, \mathbf{b} 250-63 \mu \mathrm{m}, \mathbf{c}$ 63-20 $\mu \mathrm{m}, \mathbf{d} 20-2 \mu \mathrm{m}$, and $\mathbf{e}$ $<2 \mu \mathrm{m}$
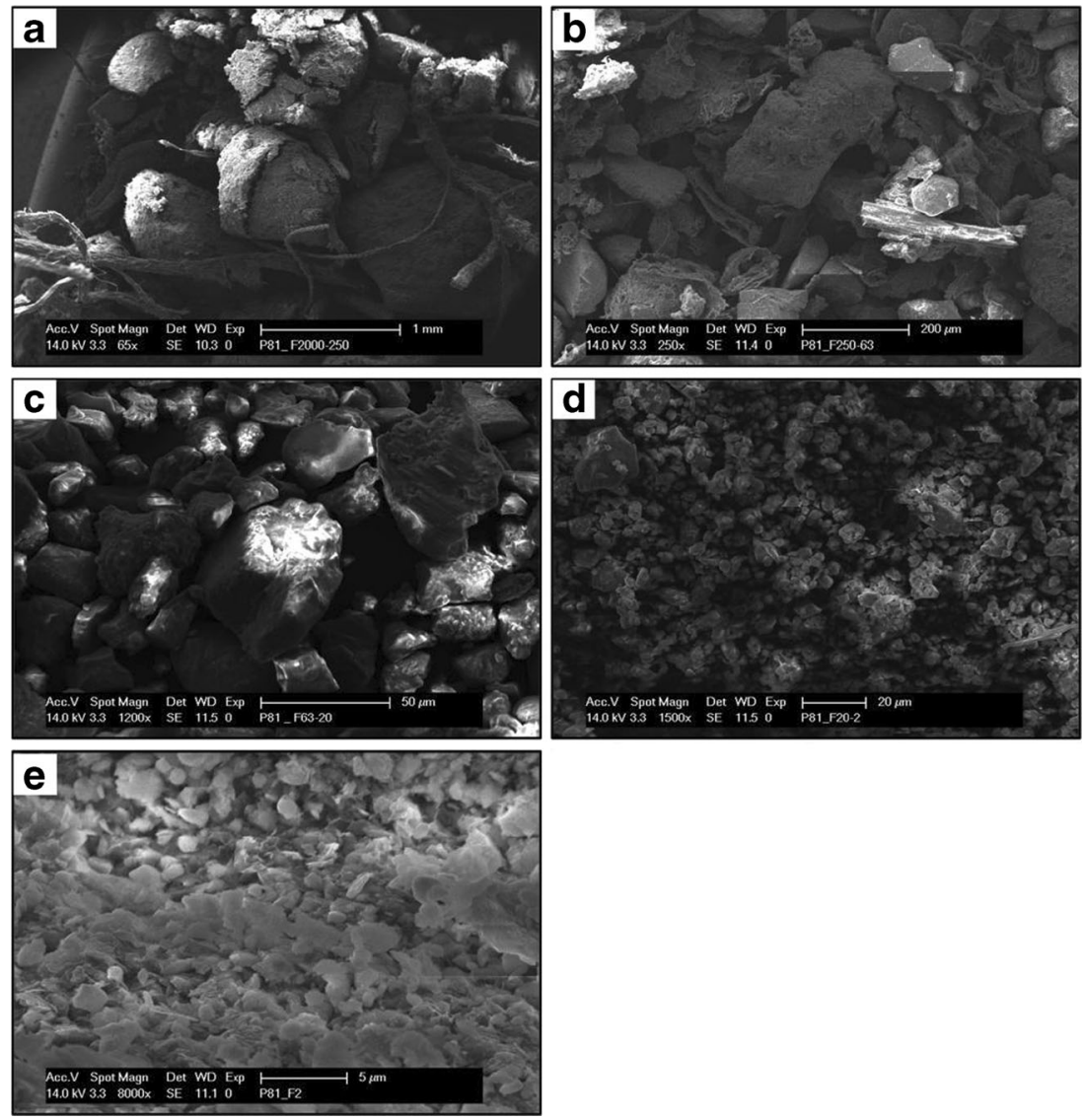

Table 1 Physicochemical characteristics of the bulk soils and their size fractions

\begin{tabular}{llllll}
\hline Site & Sample & Weight distribution (\%) & Organic carbon & Total nitrogen & C/N \\
\hline Grassland & $2,000-250 \mu \mathrm{m}$ & $11.7(1)$ & $27.06 \pm 0.17(\mathrm{a}, 1)$ & $2.18 \pm 0.06(\mathrm{~b}, 1)$ & $12.39 \pm 0.3(\mathrm{ab}, 2)$ \\
& $250-63 \mu \mathrm{m}$ & $7.2(1)$ & $20.61 \pm 0.04(\mathrm{c}, 2)$ & $1.51 \pm 0.01(\mathrm{c}, 1)$ & $13.61 \pm 0.13(\mathrm{a}, 2)$ \\
& $63-20 \mu \mathrm{m}$ & $20.8(2)$ & $6.77 \pm 0.12(\mathrm{e}, 1)$ & $0.55 \pm 0.03(\mathrm{~d}, 1)$ & $12.25 \pm 0.76(\mathrm{~b}, 1)$ \\
& $20-2 \mu \mathrm{m}$ & $42.5(1)$ & $22.83 \pm 0.13(\mathrm{~b}, 2)$ & $2.55 \pm 0.08(\mathrm{a}, 1)$ & $8.97 \pm 0.31(\mathrm{c}, 2)$ \\
& $2 \mu \mathrm{m}$ & $13.8(1)$ & $18.36 \pm 1.31(\mathrm{~d}, 2)$ & $2.27 \pm 0.08(\mathrm{~b}, 2)$ & $8.08 \pm 0.29(\mathrm{c}, 1)$ \\
No-till cropland & - & $18.16 \pm 0.23(\mathrm{I})$ & $1.82 \pm 0.05(\mathrm{I})$ & $9.96 \pm 0.18(\mathrm{II})$ \\
& Bulk soil & $9.0(1,2)$ & $18.49 \pm 0.53(\mathrm{bc}, 2)$ & $1.59 \pm 0.02(\mathrm{~b}, 2)$ & $11.6 \pm 0.29(\mathrm{~b}, 3)$ \\
& $2,000-250 \mu \mathrm{m}$ & $5.9(1,2)$ & $17.49 \pm 0.41(\mathrm{c}, 3)$ & $1.26 \pm 0.02(\mathrm{c}, 2)$ & $13.87 \pm 0.15(\mathrm{a}, 2)$ \\
& $250-63 \mu \mathrm{m}$ & $28.3(1,2)$ & $3.93 \pm 0.04(\mathrm{~d}, 3)$ & $0.3 \pm 0.01(\mathrm{~d}, 3)$ & $13.26 \pm 0.52(\mathrm{a}, 1)$ \\
& $63-20 \mu \mathrm{m}$ & $41.7(1)$ & $23.69 \pm 0.33(\mathrm{a}, 1)$ & $2.59 \pm 0.07(\mathrm{a}, 1)$ & $9.16 \pm 0.21(\mathrm{c}, 12)$ \\
& $20-2 \mu \mathrm{m}$ & $13.2(1)$ & $19.51 \pm 0.26(\mathrm{~b}, 1)$ & $2.55 \pm 0.02(\mathrm{a}, 1)$ & $7.64 \pm 0.11(\mathrm{~d}, 2)$ \\
Till cropland & $2 \mu \mathrm{m}$ & - & $18.3 \pm 0.39(\mathrm{I})$ & $1.87 \pm 0.03(\mathrm{I})$ & $9.8 \pm 0.36(\mathrm{II})$ \\
& Bulk soil & $7.9(2)$ & $17.92 \pm 0.11(\mathrm{~b}, 2)$ & $1.08 \pm 0.01(\mathrm{~d}, 3)$ & $16.54 \pm 0.2(\mathrm{a}, 1)$ \\
& $2,000-250 \mu \mathrm{m}$ & $4.2(1,2)$ & $24.16 \pm 0.38(\mathrm{a}, 1)$ & $1.47 \pm 0.04(\mathrm{c}, 1)$ & $16.4 \pm 0.31(\mathrm{a}, 1)$ \\
& $250-63 \mu \mathrm{m}$ & $27.3(1)$ & $4.67 \pm 0.12(\mathrm{e}, 2)$ & $0.35 \pm 0.01(\mathrm{e}, 2)$ & $13.38 \pm 0.09(\mathrm{~b}, 1)$ \\
& $63-20 \mu \mathrm{m}$ & $42.1(1)$ & $16.27 \pm 0.07(\mathrm{c}, 3)$ & $1.72 \pm 0.02(\mathrm{~b}, 2)$ & $9.45 \pm 0.1(\mathrm{c}, 1)$ \\
& $20-2 \mu \mathrm{m}$ & $16.3(1)$ & $14.2 \pm 0.07(\mathrm{~d}, 3)$ & $1.93 \pm 0.03(\mathrm{a}, 3)$ & $7.34 \pm 0.11(\mathrm{~d}, 3)$ \\
& $2 \mu \mathrm{m}$ & - & $13.9 \pm 0.45(\mathrm{II})$ & $1.28 \pm 0.01(\mathrm{II})$ & $10.88 \pm 0.45(\mathrm{I})$ \\
\hline
\end{tabular}

Organic carbon and total nitrogen are expressed as grams per kilogram of sample. Means $( \pm)$ standard deviations were calculated on triplicates $(n=3)$. Roman numerals, letters, and numbers enclosed in parentheses indicate significant differences at $P<0.05$ of a variable between the different bulk soils, the different size fractions of a given soil, and between land management for a given size fraction, respectively 
Fig. 3 Bacterial density among size fractions and bulk soils. Error bars represent the standard deviation $(n=3)$. Different roman numerals, letters, and numbers indicate significant differences at $P<0.05$ of a variable between the different bulk soils, the different size fractions of a given soil, and between land management for a given size fraction, respectively. Black, grassland; light gray, no-till cropland; dark gray, till cropland

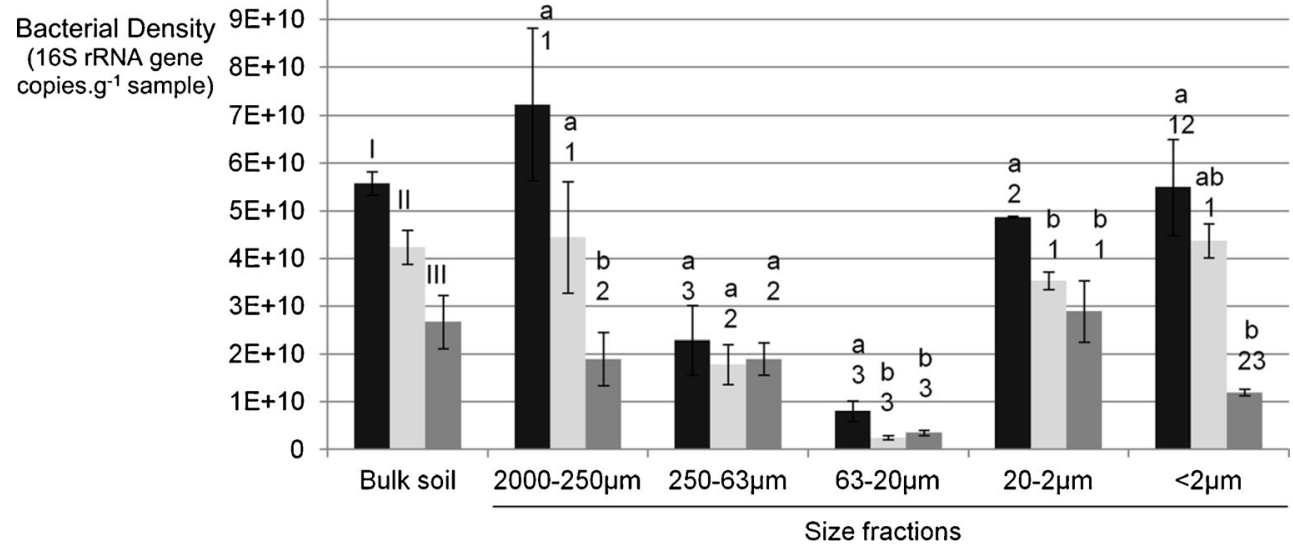

the tilled soil, thereby stressing that cropping intensity reduces soil environmental heterogeneity at a microscale and thus soil biological variability.

3.3 Response of soil bacterial diversity to cropping intensity at a microscale

A lower Shannon diversity index was recorded in the tilled bulk soil (5.38) as compared to the grassland (5.46) and no-till soils (5.50), confirming the negative impact of this agricultural practice on soil microorganisms (Table 2). Bacterial richness and Shannon indexes were positively correlated with organic carbon $(R=0.723$ and 0.891$)$ and total nitrogen contents $(R=$ 0.760 and 0.880$)$ and negatively with $\mathrm{C} / \mathrm{N}$ ratios $(R=-0.696$ and -0.708 ), whereas no significant correlation was observed for evenness.

Similarly to bacterial density, a heterogeneous distribution of the bacterial diversity among microenvironments was apparent from comparison of richness, evenness, and Shannon diversity indexes (Table 2). This observation is supported by results from studies using various fractionation procedures (Davinic et al. 2012), molecular techniques to assess diversity of bacterial (Ranjard et al. 2000; Mummey et al. 2006), or fungal communities (Ruamps et al. 2010) in microenvironments. Bacterial richness followed a similar distribution pattern among the size fractions in the three soils with the highest number of OTUs in the medium size fractions (250-63 and 63-20 $\mu \mathrm{m}$, Table 2). These data are not in agreement with those of Davinic et al. (2012) who reported on the highest
Table 2 Bacterial diversity in bulk soils and size fractions

Means and $( \pm)$ standard deviations were calculated on replicates $(n=3)$. Roman numerals inside the parentheses indicate significant differences at $P<0.05$ of a bacterial community variable between the different bulk soils. Letters and numbers inside the parentheses indicate significant differences at $P<0.05$ of a bacterial community variable between the different size fractions of a given soil and between land management for a given size fraction, respectively

\begin{tabular}{lllll}
\hline Site & Sample & Richness & Evenness & Shannon index \\
\hline Grassland & $2,000-250 \mu \mathrm{m}$ & $486 \pm 16(\mathrm{~b}, 1)$ & $0.853 \pm 0.003(\mathrm{a}, 1)$ & $5.27 \pm 0.05(\mathrm{ab}, 1)$ \\
& $250-63 \mu \mathrm{m}$ & $539 \pm 14(\mathrm{a}, 1)$ & $0.852 \pm 0.001(\mathrm{a}, 1)$ & $5.35 \pm 0.03(\mathrm{a}, 1)$ \\
& $63-20 \mu \mathrm{m}$ & $481 \pm 17(\mathrm{~b}, 2)$ & $0.844 \pm 0.004(\mathrm{a}, 1)$ & $5.21 \pm 0.04(\mathrm{bc}, 2)$ \\
& $20-2 \mu \mathrm{m}$ & $472 \pm 19(\mathrm{~b}, 2)$ & $0.845 \pm 0.007(\mathrm{a}, 1)$ & $5.21 \pm 0.08(\mathrm{bc}, 1)$ \\
& $2 \mu \mathrm{m}$ & $459 \pm 14(\mathrm{~b}, 1)$ & $0.831 \pm 0.005(\mathrm{~b}, 1)$ & $5.09 \pm 0.05(\mathrm{c}, 1)$ \\
No-till cropland & $554 \pm 12(\mathrm{I} \mathrm{II})$ & $0.864 \pm 0.006(\mathrm{I})$ & $5.46 \pm 0.05(\mathrm{I})$ \\
& Bulk soil & $495 \pm 24(\mathrm{bc}, 1)$ & $0.847 \pm 0.004(\mathrm{ab}, 1)$ & $5.26 \pm 0.05(\mathrm{a}, 1)$ \\
& $2,000-250 \mu \mathrm{m}$ & $517 \pm 3(\mathrm{ab}, 1)$ & $0.845 \pm 0.006(\mathrm{ab}, 1)$ & $5.28 \pm 0.04(\mathrm{a}, \mathrm{b})$ \\
& $250-63 \mu \mathrm{m}$ & $556 \pm 29(\mathrm{a}, 1)$ & $0.854 \pm 0.005(\mathrm{a}, 1)$ & $5.39 \pm 0.07(\mathrm{a}, 1)$ \\
& $63-20 \mu \mathrm{m}$ & $445 \pm 25(\mathrm{c}, 1)$ & $0.833 \pm 0.004(\mathrm{~b}, 1)$ & $5.08 \pm 0.06(\mathrm{~b}, 1)$ \\
& $20-2 \mu \mathrm{m}$ & $448 \pm 14(\mathrm{c}, 2)$ & $0.790 \pm 0.008(\mathrm{c}, 1)$ & $4.82 \pm 0.05(\mathrm{c}, 2)$ \\
& $2 \mu \mathrm{m}$ & $594 \pm 24(\mathrm{I})$ & $0.861 \pm 0.004(\mathrm{I})$ & $5.50 \pm 0.04(\mathrm{I})$ \\
& Bulk soil & $438 \pm 6(\mathrm{~b}, 2)$ & $0.739 \pm 0.005(\mathrm{~d}, 2)$ & $4.49 \pm 0.02(\mathrm{~d}, 2)$ \\
& $2,000-250 \mu \mathrm{m}$ & $457 \pm 5(\mathrm{a}, 2)$ & $0.761 \pm 0.002(\mathrm{c}, 2)$ & $4.66 \pm 0.01(\mathrm{c}, 3)$ \\
& $250-63 \mu \mathrm{m}$ & $434 \pm 8(\mathrm{~b}, 2)$ & $0.779 \pm 0.004(\mathrm{~b}, 2)$ & $4.73 \pm 0.01(\mathrm{~b}, 3)$ \\
& $63-20 \mu \mathrm{m}$ & $443 \pm 5(\mathrm{~b}, 1)$ & $0.802 \pm 0.002(\mathrm{a}, 2)$ & $4.88 \pm 0.02(\mathrm{a}, 2)$ \\
& $20-2 \mu \mathrm{m}$ & $409 \pm 10(\mathrm{c}, 3)$ & $0.736 \pm 0.002(\mathrm{~d}, 3)$ & $4.43 \pm 0.01(\mathrm{e}, 3)$ \\
& $2 \mu \mathrm{m}$ & $541 \pm 12(\mathrm{II})$ & $0.856 \pm 0.002(\mathrm{I})$ & $5.38 \pm 0.03(\mathrm{II})$ \\
\hline
\end{tabular}


diversity in coarse and fine fractions $(>250$ and $<53 \mu \mathrm{m}$, respectively). In our case, the microscale distribution of bacterial richness might be related to the level of protection of microenvironment which is dependent on the size and stability of soil aggregates (Vos et al. 2013). Indeed, microorganisms indigenous to macroaggregates $>250 \mu \mathrm{m}$ are more exposed to environmental variations (humidity, aeration, accessibility of nutrients and toxic compounds, and predation), whereas in microaggregates $<20 \mu \mathrm{m}$, they are more protected (Ranjard and Richaume 2001; Mummey et al. 2006; Vos et al. 2013). As a consequence, microorganisms indigenous to intermediate size fractions (250-63 and 63-20 $\mu \mathrm{m}$ ) would be exposed to an intermediate level of environmental perturbation. According to the "hump backed" model that links the biodiversity to the intensity of its exposure to environmental stresses, our results suggested that bacteria indigenous to intermediate size fractions may be exposed to moderate perturbations, which led to a decrease in the competitive niche exclusion and selection mechanisms occurring between populations, and consequently to an increase in bacterial richness (Giller et al. 1998).

Bacterial evenness was not distributed in the same way as richness since it decreased with the size of the fractions in grassland soil (Table 2). In this case, evenness may be altered by the high level of protection of the microhabitats (as described above) and by the biochemical quality of soil organic matter. Puget et al. (2000) demonstrated that the organic matter in microaggregates is more stable and recalcitrant to microbial degradation, leading to a strong selection of particular populations which become dominant and thereby alter the bacterial evenness.

As observed for microbial abundance, evenness and richness were systematically lower in all the microenvironments under tillage as compared to grassland and no-till crop soils. More precisely, a loss of richness ranging from 4 to $11 \%$ among the different microenvironments of the tilled soil as compared to the soil under grassland was recorded (Table 2). This supports the hypothesis that the till crop system represents an important perturbation that affects bacterial diversity even in protected microenvironments (Ranjard and Richaume 2001). For evenness, various magnitudes of decrease were recorded according to the size of the fraction. This led to a particular distribution with the highest evenness measured in the microaggregated fractions (from 250 to $2 \mu \mathrm{m}$ ) and the lowest in the macroaggregated ones $(>250 \mu \mathrm{m})$. Although not congruent with the distribution of the $\mathrm{C} / \mathrm{N}$ ratio, this might be explained by the low level of protection provided by the coarsest fraction under tillage which would lead to the selection of particular bacterial populations adapted to strong variations in environmental conditions (Six et al. 2004). As previously observed for bacterial abundance, soil tillage led to a strong homogenization of the microscale distribution of bacterial diversity, confirming the loss of soil heterogeneity and biological variability between microenvironments.
3.4 Response of soil bacterial composition to cropping intensity at a microscale

A cluster analysis was performed to determine the similarity of the bacterial communities between the different size fractions and bulk soils (Fig. 4). Four clusters were significantly discriminated. The first cluster (I) evidenced the discrimination between bulk soils and the microenvironments. In this cluster, the two crop soils were discriminated from the grassland soil. Cluster II regrouped coarse fractions $(>20 \mu \mathrm{m})$ from the grassland and no-till soils with two sub-clusters discriminated on the size of the fractions. Cluster III grouped exclusively the size fractions from tilled soil except the $20-2 \mu \mathrm{m}$. Cluster IV grouped the fine fractions $(20-2$ and $<2 \mu \mathrm{m}$ ) from all three soils. More precisely, the fine fractions of grassland soil were grouped together and discriminated from the fine fractions of the tilled and no-till soils (Fig. 4).

Altogether, cluster analysis of bacterial OTU composition revealed that whole communities of bulk soils were more similar to those of the coarse and medium size fractions $(>20 \mu \mathrm{m})$. This result is not in agreement with reports relating that the microaggregated fractions mainly participate in the whole community structure (Ranjard et al. 2000), or with the higher relative abundance of microaggregated fractions combined with their high indigenous bacterial density as described above (Table 1 and Fig. 3).

Coarse and medium size fractions $(>20 \mu \mathrm{m})$ were grouped according to land management, whereas the finest fractions, and especially the microaggregated fractions $(20-2 \mu \mathrm{m})$, were grouped according to their size. Similar results have been reported for different soil types and land management (Mummey et al. 2006). This observation might be related to the processes of community assemblage resulting from the balance between the effects of contemporary environmental conditions versus historical contingencies (Martiny et al. 2006). By providing the greatest and most permanent level of protection for bacteria, microaggregates host a specific community structure, which may result mainly from historical contingency and therefore reflect the soil type. In contrast, in less stable and less protected macroaggregates, the community structure may result mainly from contemporary variations of environmental conditions and, thus, reflect the current land management. A similar hypothesis has already been proposed for explaining distance effects in biogeographical studies (Martiny et al. 2006).

A significant decrease $(P<0.001)$ of average community dissimilarity between microenvironments was recorded according to cropping intensity with grassland $(0.86) \geq$ no-till crop system $(0.85)>$ till crop system $(0.81)$. This observation is consistent with those made for bacterial density and richness and stresses the significant homogenization of the microscale distribution of bacterial community induced by soil disturbance. The taxonomic affiliation of 16S rRNA sequences 

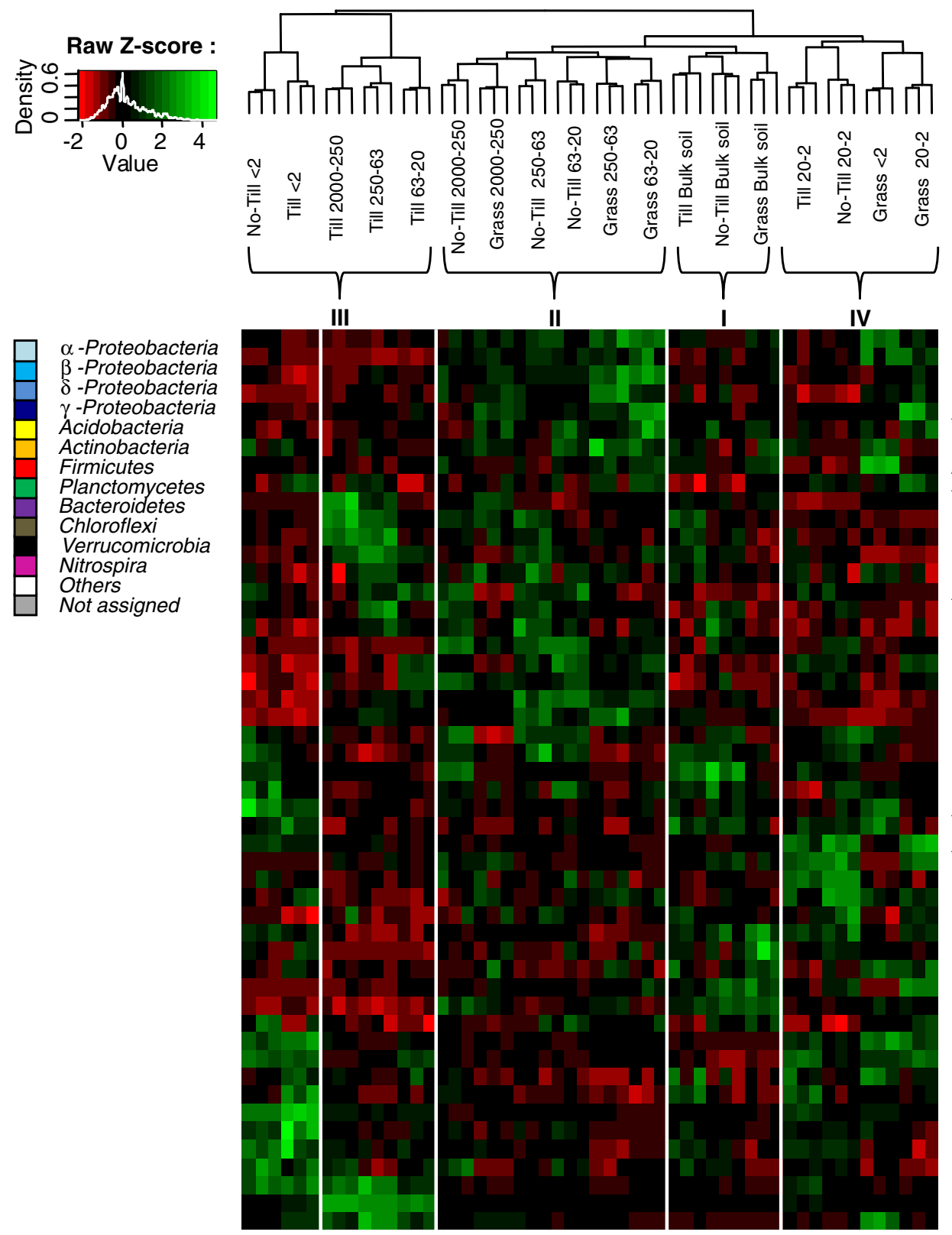

Phyllobacterium Mycobacterium Steroidobacter Mesorhizobium Agromyces Solirubrobacter Gp17

Zavarzinella Acidovorax Flavobacterium Devosia Rhizobium Hyphomicrobium Gp10 Arenimonas Phenylobacterium Pedomicrobium Kribbella Nocardioides Microvirga Microvirga Ohtaekwangia Bacillus Planctomyces Nitrospira Pasteuria Aquicella Gp 4 Adhaeribacter Akermanella Ferruginibacter Chlorophyta Variovorax Sub3.incert.Sedis Spartobacteria Gemmata Microlunatus Gp6 Clostridium Lysobacter Gp7. Terrimonas Pseudomonas Flavisolibacter Gemmatimonas Paenibacillus Naxibacter Massilia

Brevundimonas

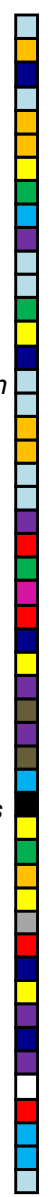

Fig. 4 Cluster analysis and heatmap of the genus composition of the bacterial communities in bulk soils and size fractions. Cluster tree was based on the OTU composition and constructed using UPGMA dendrogram of weighted UniFrac phylogenetic community distance. Numbers I to $I V$ indicated the significant clusters identified. Genera relative abundance were identified in each sample by colors deduced from the raw $Z$ scores. The values were median centered, and the colors are scaled to standard deviation showed that whatever soils and microenvironments, phyla distribution was systematically dominated by Proteobacteria (ranging from 41.1 to $68.1 \%$ ) and especially by $\alpha$ Proteobacteria, followed by Actinobacteria (6.4 to $20.3 \%$ ), Bacteroides (7.8 to $11.4 \%$ ), Acidobacteria (3.9 to $7.9 \%$ ), Planctomycetes (2.1 to $4.9 \%$ ), and Firmicutes (3 \%, Fig. 4). At the genus level, all samples were dominated by Acidobacteria Gp6 (ranging from 2.6 to $5.9 \%$ ), Pseudomonas (0.7 to $17.2 \%$ ), Massilia (0.2 to $17.2 \%)$, Lysobacter (1.0 to $4.4 \%$ ), and Bradyrhizobium (0.4 to $2.7 \%$ ).
A multivariate analysis based on genus composition was performed to discriminate the different soils and microenvironments according to agricultural land management (data not shown) and to highlight the significant variations of particular genus visually observed in the heatmap (Fig. 4). Bulk grassland soil hosted a higher abundance of bacteria belonging to Actinobacteria phyla and Acidobacteria Gp6, which are Kstrategists and recurrently observed in undisturbed grassland soils (Bernard et al. 2007; Naether et al. 2012). On the other hand, crop soils exhibited a higher relative abundance of 
populations described as r-strategists, opportunistic, and copiotrophic bacterial genus such as Pseudomonas, Variovorax, Bacillus, Devosia and Planctomyces which are adapted to adverse surrounding conditions, thereby confirming that cropping induced environmental perturbation (Fierer et al. 2007).

At a microscale, Rhizobium ( $\alpha$-Proteobacteria), Ohtaekwangia (Bacteroidetes) Kribbella (Actinobacteria), and Devosia ( $\alpha$-Proteobacteria) were mainly observed in coarse and medium size fractions $(>20 \mu \mathrm{m})$ in grassland soil, whereas Pseudomonas ( $\gamma$-Proteobacteria), Clostridium (Firmicutes), and Lysobacter ( $\gamma$-Proteobacteria) occurred mainly in the fine-sized fractions. Davinic et al. (2012) reported on similar findings with a higher occurrence of Actinobacteria, Bacteroidetes (Ohtaekwangia), and $\alpha$ Proteobacteria phyla in macroaggregated fractions and a predominance of $\beta$ - and $\gamma$-Proteobacteria in microaggregated fractions. In macroaggregates, the prevalence of Rhizobia might be related to the strong interactions of this group with plant roots located exclusively in the soil macroporosity (Tighe et al. 2000). On the other hand, the presence of Kribbella might result from their particular hyphae structure that limits their colonization to the soil macroporosity (Trujillo et al. 2005). In microaggregates, the preferential occurrence of Pseudomonas and Lysobacter genera, which are described as copiotrophs and $r$-strategists might be partly result from the large amount of soil organic matter in these microenvironments (Fierer et al. 2007; Bernard et al. 2007).

The higher relative abundance of Acidobacteria (Gp6, Gp4, Gp17, and Spartobacter) and Agromyces (Actinobacteria) genus in the microenvironments of grassland soil matches with recent reports concerning the detection of such bacteria in grassland soils and undisturbed terrestrial environments (Naether et al. 2012). The higher occurrence of Pedomicrobium and Rhizobia under no-till and grassland conditions may result from their interactions with plant rhizosphere, which are optimum in undisturbed soils (Tighe et al. 2000). In the microenvironments of the tilled soil, the systematic higher occurrence of Massillia and Pseudomonas might be explained by their copiotrophic and r-strategist attributes which are required in perturbed soils and responsible for the flush of organic matter mineralization generally observed after tillage (Bastian et al. 2009).

\section{Conclusion}

Altogether, our results evidenced a heterogeneous distribution of bacterial community in soils at a microscale but also clearly demonstrate that agricultural land management induces deep modifications of soil bacterial abundance and diversity in the different soil microhabitats. The loss of soil biological variability and therefore of diversity at a microscale related to cropping intensity may lead to a loss of the resilience and resistance capacities to environmental perturbation of the whole soil microbial community according to the "ecological insurance" concept described by Yachi and Loreau (1999). Further analysis of the functional performance of bacterial community in the different soil microenvironments is required to confirm this hypothesis. However, in an agroecological context, innovative and sustainable agricultural practices should be adopted in order to better maintain the innate biological variability by preserving the integrity of the natural mosaic of soil microhabitats.

Acknowledgments This work, through the involvement of technical facilities of the GenoSol platform of the infrastructure ANAEE-Services, received a grant from the French State through the National Agency for Research under the program "Investments for the Future" (reference ANR-11-INBS-0001), as well as grant from the Regional Council of Burgundy. We would like to thank the farmers of Fénay for providing us agricultural practices and for allowing us to perform soil sampling on their fields. Thanks are also extended to D Warwick for comments to the manuscript.

\section{References}

Bastian F, Bouziri L, Nicolardot B, Ranjard L (2009) Impact of wheat straw decomposition on successional patterns of soil microbial community structure. Soil Biol Biochem 41(2):262-275. doi:10. 1016/j.soilbio.2008.10.024

Bernard L, Mougel C, Maron P-A, Nowak V, Lévêque J, Henault (2007) Dynamics and identification of soil microbial populations actively assimilating carbon from 13C-labelled wheat residue as estimated by DNA- and RNA-SIP techniques. Environ Microbiol 9(3):752764. doi:10.1111/j.1462-2920.2006.01197.x

Chotte J, Schwartzmann A, Bally R, Jocteur Monrozier L (2002) Changes in bacterial communities and Azospirillum diversity in soil fractions of a tropical soil under 3 or 19 years of natural fallow. Soil Biol Biochem 34:1083-1092

Davinic M, Fultz LM, Acosta-Martinez V, Calderón FJ, Cox SB, Dowd SE et al (2012) Pyrosequencing and mid-infrared spectroscopy reveal distinct aggregate stratification of soil bacterial communities and organic matter composition. Soil Biol Biochem 46:63-72. doi: 10.1016/j.soilbio.2011.11.012

Delmont TO, Robe P, Cecillon S, Clark IM, Constancias F, Simonet P et al (2011) Accessing microbial diversity for soil metagenomic studies. Appl Environ Microbiol 77(4):1315-1324. doi:10.1128/ AEM.01526-10

Dequiedt S, Saby NPA, Lelievre M, Jolivet C, Thioulouse J, Toutain B et al (2011) Biogeographical patterns of soil molecular microbial biomass as influenced by soil characteristics and management. Glob Ecol Biogeogr 20(4):641-652. doi:10.1111/j.1466-8238.2010. 00628.x

Fierer N, Jackson RB (2006) The diversity and biogeography of soil bacterial communities. Proc Natl Acad Sci U S A 103(3):626-631. doi:10.1073/pnas.0507535103

Fierer N, Bradford MA, Jackson RB (2007) Toward an ecological classification of soil bacteria. Ecology 88(6):1354-1418

Giller KE, Witter E, Mcgrath SP (1998) Toxicity of heavy metals to microorganisms and microbial processes in agricultural soils: a 
review. Soil Biol Biochem 30(10-11):1389-1414. doi:10.1016/ S0038-0717(97)00270-8

Hol WHG, de Boer W, Termorshuizen AJ, Meyer KM, Schneider JHM, van Dam NM et al (2010) Reduction of rare soil microbes modifies plant-herbivore interactions. Ecol Lett 13(3):292-301. doi:10.1111/ j. 1461-0248.2009.01424.x

Knight R, Maxwell P, Birmingham A, Carnes J, Caporaso JG et al (2007) PyCogent: a toolkit for making sense from sequence. Genome Biol 8(8):R171

Lienhard P, Terrat S, Prévost-Bouré NC, Nowak V, Régnier T, Sayphoummie $S$ et al (2013) Pyrosequencing evidences the impact of cropping on soil bacterial and fungal diversity in Laos tropical grassland. Agron Sustain Dev. doi:10.1007/s13593-013-0162-9

Lozupone C, Knight R (2005) UniFrac: a new phylogenetic method for comparing microbial communities. Appl Environ Microbiol 71(12): 8228-8235. doi:10.1128/AEM.71.12.8228

Maron P-A, Mougel C, Ranjard L (2011) Soil microbial diversity: methodological strategy, spatial overview and functional interest. C R Biol 334:403-414

Martiny JBH, Bohannan BJM, Brown JH, Colwell RK, Fuhrman J, Green JL et al (2006) Microbial biogeography: putting microorganisms on the map. Nat Rev Microbiol 4(2):102-112. doi:10.1038/ nrmicro1341

Mummey DL, Holben W, Six J, Stahl P (2006) Spatial stratification of soil bacterial populations in aggregates of diverse soils. Microb Ecol 51(3):404-411. doi:10.1007/s00248-006-9020-5

Naether A, Foesel B, Naegele V, Wüst K, Weinert J, Bonkowski M et al (2012) Environmental factors affect acidobacterial communities below the subgroup level in grassland and forest soils. Appl Environ Microbiol 78:7398-7406

Nunan N, Wu K, Young IM, Crawford JW, Ritz K (2003) Spatial distribution of bacterial communities and their relationships with the micro-architecture of soil. FEMS Microbiol Ecol 44(2):203215. doi:10.1016/S0168-6496(03)00027-8

Olchin GP, Ogle S, Frey SD, Filley TR, Paustian K, Six J (2008) Residue carbon stabilization in soil aggregates of no-till and tillage management of dryland cropping systems. Soil Sci Soc Am J 72(2):507. doi:10.2136/sssaj2006.0417

Oorts K, Bossuyt H, Labreuche J, Merckx R, Nicolardot B (2007) Carbon and nitrogen stocks in relation to organic matter fractions, aggregation and pore size distribution in no-tillage and conventional tillage in northern France. Eur J Soil Sci 58(1):248-259. doi:10.1111/j. 1365-2389.2006.00832.x

Plassart P, Tedersoo L, Thomson B, Griffiths R, Dequiedt S, Lelievre M et al (2012) Evaluation of the ISO standard 11063 DNA extraction procedure for assessing soil microbial abundance and community structure. PLoS One 7(9):e44279
Prosser JI, Bohannan BJM, Curtis TP, Ellis RJ, Firestone MK, Freckleton RP et al (2007) The role of ecological theory in microbial ecology. Nat Rev Microbiol 5(5):384-392. doi:10.1038/nrmicro1643

Puget P, Chenu C, Balesdent J (2000) Dynamics of soil organic matter associated with particle-size fractions of water-stable aggregates. Eur J Soil Sci 51:595-605

Quast C, Pruesse E, Yilmaz P, Gerken J, Schweer T, Yarza P et al (2013) The SILVA ribosomal RNA gene database project: improved data processing and web-based tools. Nucleic Acids Res 41(Database issue):D590-D596. doi:10.1093/nar/gks1219

Ranjard L, Richaume A (2001) Quantitative and qualitative microscale distribution of bacteria in soil. Res Microbiol 152(8):707-716

Ranjard L, Poly F, Combrisson J, Richaume A, Gourbiere F, Thioulouse J, Nazaret S (2000) Heterogeneous cell density and genetic structure of bacterial pools associated with various soil microenvironments as determined by enumeration and DNA fingerprinting approach (RISA). Microb Ecol 39(4):263-272. doi:10.1007/s002480000032

Ruamps LS, Nunan N, Chenu C (2010) Microbial biogeography at the soil pore scale. Soil Biol Biochem 43(2):280-286. doi:10.1016/j. soilbio.2010.10.010

Six J, Bossuyt H, Degryze S, Denef K (2004) A history of research on the link between (micro) aggregates, soil biota, and soil organic matter dynamics. Soil Tillage Res 79(1):7-31. doi:10.1016/j.still.2004.03.008

Terrat S, Christen R, Dequiedt S, Lelièvre M, Nowak V, Regnier T et al (2012) Molecular biomass and MetaTaxogenomic assessment of soil microbial communities as influenced by soil DNA extraction procedure. Microb Biotechnol 5(1):135-141. doi:10.1111/j.17517915.2011.00307.x

Tighe SW, de Lajudie P, Dipietro K, Lindström K, Nick G, Jarvis BD (2000) Analysis of cellular fatty acids and phenotypic relationships of Agrobacterium, Bradyrhizobium, Mesorhizobium, Rhizobium and Sinorhizobium species using the Sherlock Microbial Identification System. Int J Syst Evol Microbiol 50(2):787-801

Trujillo M, Willems A, Abril A, Planchuelo A, Rivas R, Ludena D et al (2005) Nodulation of Lupinus albus by Strains of Ochrobactrum lupini sp nov. Appl Environ Microbiol 71:1318-1327. doi:10.1128/ AEM.71.3.1318

Vos M, Wolf AB, Jennings SJ, Kowalchuk GA (2013) Micro-scale determinants of bacterial diversity in soil. FEMS Microbiol Rev. doi:10.1111/1574-6976.12023

Yachi S, Loreau M (1999) Biodiversity and ecosystem productivity in a fluctuating environment: the insurance hypothesis. Proc Natl Acad Sci U S A 96(February):1463-1468

Zinger L, Lejon DPH, Baptist F, Bouasria A, Aubert S, Geremia RA, Choler P (2011) Contrasting diversity patterns of crenarchaeal, bacterial and fungal soil communities in an alpine landscape. PloS One 6(5):e19950. doi:10.1371/journal.pone.0019950 